\title{
Public Art in the Tropics Education Conduit Community Catalyst
}

\section{Linda Ashton}

Dr Linda Ashton is Senior Lecturer in the School of Education, JCU.

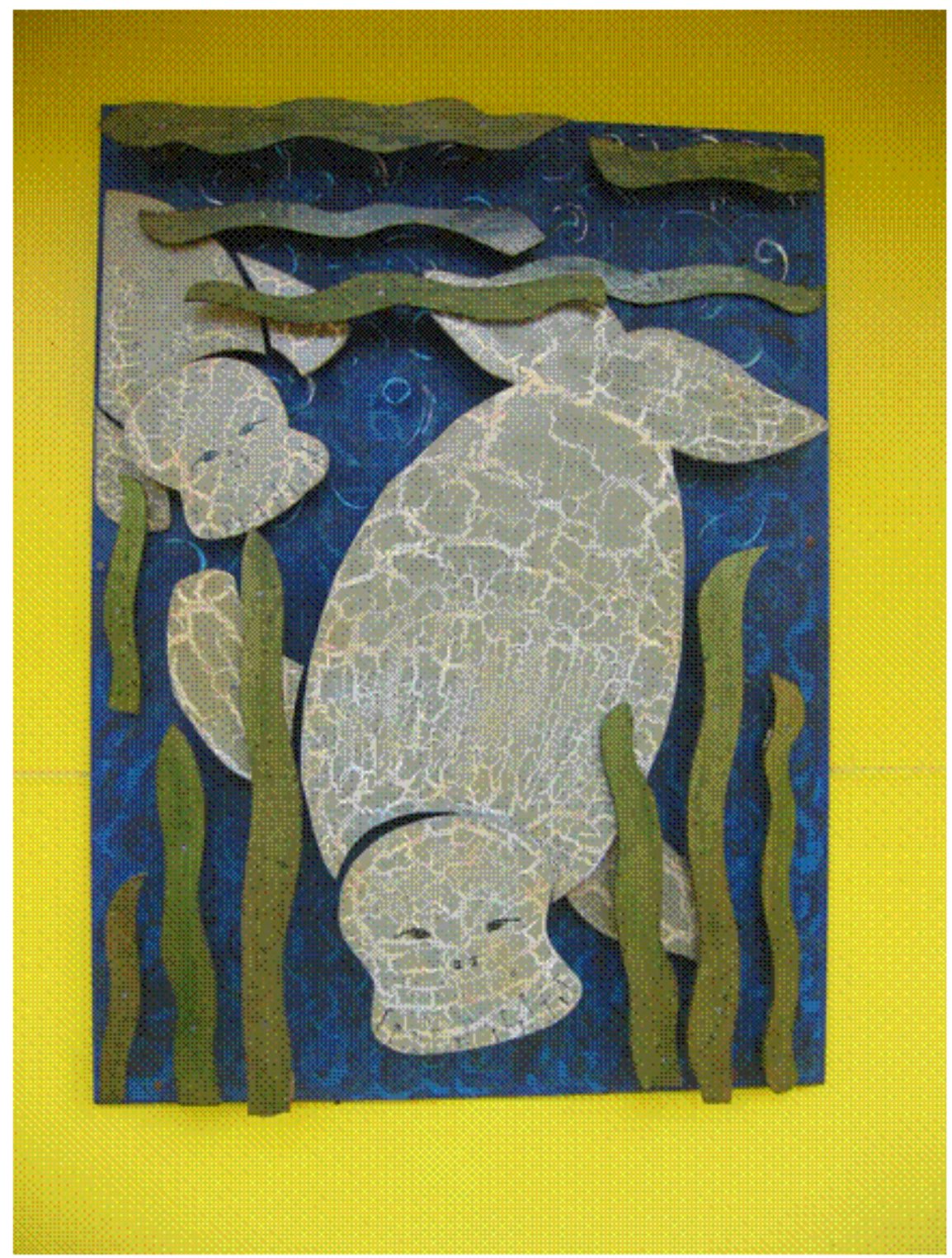

\section{Abstract}

As part of art education studies, pre-service teachers at JCU have been active in public and community art projects 1999-2009. These works for and with diverse regional communities have been varied, challenging and on a number of levels, highly successful. A consistent theme in the works is the wet and dry tropical imagery of North Queensland. A visual 
overview will be presented of major projects to illustrate highlights, lowlights and issues. The presentation will celebrate imagination, diversity and how the process of making large scale artworks can be a catalyst for collaboration, education, research, lateral thinking, commitment to active citizenship and facilitation of strong, inclusive community partnerships. Key words: public art tropics issues community-building art education collaboration

In this paper key public and community art issues and terms are discussed. The context for James Cook University pre-service teacher engagement in the field, since 1999, is summarized. The intention is to feature imagination and collaboration in the multiple and varied art projects completed by the School of Education. Collaborating to create large art works for and with local communities can enhance future teachers' understanding of how these public genres differ dramatically in both style and motivation from conventional fine art works made by an individual artist. Before initiating and managing their own projects in schools, pre-service teachers must know from first hand experience that for group projects there are significant risks as well as remarkable educational and social benefits. For ten years this has been a major focus of my undergraduate teaching in an elective subject at JCU and the cornerstone of my community engagement in the local tropical region.

Our University is located in North Queensland and committed to research, teaching and community engagement in the tropics. This focus along with the glorious array of wet and dry tropical colours, shapes and textures provides endless inspiration for our public art projects. The accompanying visuals show how animals and plant forms are highly significant when representing the tropical place where we live and work. Flora and fauna from The Great Barrier Reef, rainforest and the outback have featured in our ceramic relief works, painted murals, mosaics, fence panels and even recycled tree stumps. A recurring feature is the use of mirror, which provides real and metaphoric reflection of the community and its surroundings in the artworks. While celebrating cultural diversity and the natural environment, our projects are also increasingly responsive to environmental impact, with recycling, carbon credit strategies, tree plantings and responsible practices put in place. Making public art for local communities (and on occasions for corporate citizens) should teach the makers and the viewers about themselves, about others, about the special place which they share and must care-take. 


\section{Is It Public art or Community art or both?}

Public art is generally created for specific sites beyond conventional gallery or museum spaces. Usually professional artists are commissioned and the product is the main focus. Community art is more about process which often involves non-professional groups and a project manager who has the knowledge and experience to see the work to completion. Community art celebrates people and their relationships to each other and to place, however the end products can also be considered 'public' art. As permanent installations or ephemeral events most of these public and or community artworks are large in scale, designed for outdoor spaces allowing free public access. They fulfill various cultural and aesthetic purposes e.g. beautification, commemoration, fun, critical social comment, community identity, status signifiers, landmarks, thinking triggers and education conduits. Some of the newer genres incorporate politically-charged performances, ephemeral forms and imagery, digital projections onto buildings and a host of cultural events (Holt, 2000). Airshows, fireworks, kite festivals and even military displays and street parades, while not commonly considered public art, have many of the same features, functions and costs though ephemeral in timeframe. Historical definitions of public art more commonly refer to works made from very durable media extending chances of survival over many years.

If providing art in public spaces has in the past been a rather adhoc business, it has become big business in the C21st. The Homebush Bay works created for the 2000 Sydney Olympics totalled \$7.5 million and were the largest single commitment to public art to date in Australia (MacGowan, 2000). In concert with international trends and current Australia Council for The Arts policy, each state government has, over the last decade, developed guidelines for minimum budget allocations i.e. usually $1-2 \%$ of total project funds is to be spent on public art works for major new state department buildings over \$250 000 (Lally, 1998; Miller, A. 2000; Miller, N. 2000; Morrell, 2000). In March 1999, the first Qld state Art Built-In Policy was created with a Public Art Agency established to oversee its implementation. This was superseded by Art + Place (2007) which differs considerably through its competitive grantlike model. How this model will impact on the balance of funding for or successful submissions by regional communities, is not yet known. However, in concert with state legislation, many "local shire councils at the cutting edges are recognising the need to carefully define their role in public art and cultural development" (Ohlin, 1998: 66). For artists and art communities working in the area, this is a very welcome development as 
evidenced in the Townsville and Cairns Esplanades and Riverway complex. At other times things just appear in the public domain with minimal connection to state or national policy/guidelines or to place e.g. the new Qld Rail Terminal in Townsville and the Mundingburra Police Headquarters neither of which appear to have activated legislation at the time for the incorporation of public art.

As well as state government intent, there has been a steady increase in private sponsorship for and commissioning of eye catching public art. Many Australian cities and towns have entrepreneurs looking to enhance market value of their properties (Erikson, 1998). While there are currently no by-laws or legislation requiring corporate owners to do so, it appears that "the private sector is taking the initiative in using public art to obtain a competitive visual edge. No one from the private sector is commissioning artists to be kind. They are doing so because it makes good commercial sense" (Miller, N. 2000: 31). In 1998 Kins called for renewed dialogue about public art. I agree that there is a need to regularly review principles, practices and policies in local regions where communities and volunteers are more likely to participate in the making process. This tendency has been activated at JCU where some Education students have had the opportunity to work with the community on projects and complete scholarly assignments.

\section{Challenges}

There are complex processes and issues involved in the commissioning, design, installation and maintenance of public artworks, which need to exist unsupervised, for years in the public domain (Anderson, 2001; Brecknock, 1992; Dissanayake, 2001; Taylor, 2001). These include suitability of the product for context, quality assurance, durability, safety and public liability, cost, co-ordination of subcontractors, cultural sensitivity, community consultation, autonomy of artists, censorship, vandalism risks, pigeon poo, maintenance and decommissioning, are all critical considerations (Miles, 2001). There are ongoing debates about whether public art should be of most benefit to the artists, to the people who have no choice but to live with the art (Malone, 1997) or to the environment from which the art product is made (Baxter, 1998; Berk, 2001; Miller, 2001; Miles, 1997). As stated earlier, professional artists working alone or in a small consortium are responsible for making most outdoor public artworks. Amateur work is more often voluntary and collaborative, with larger numbers of people contributing to each project (Lally, 1998). This is the context for most of JCU's projects, for and with communities, living in the NQ tropical region. The contribution of non-professional groups, 
school students and the general community is not well documented and there is little research into their efforts or about the quality achieved. What is evident from our experience, which complements the few studies available, is that community involvement in making public art, while challenging, can be very rewarding. What is also very clear is that public and community art projects are very hard work (Baxter, 1998: 73; Cohn, 2001).

\section{The School of Education's approach}

For a full semester each year, approximately 30 Townville based education students become part of a public art team in planning, making and installing large works. In most cases this is with community/client participation. In preparation, students complete intensive drawing, digital design and creative thinking tasks and a major assignment in which public art issues are investigated. For all JCU public and community art projects, the lecturer fulfils various roles- project manager, design consultant, identifying clients, preparing proposals, recommending sites, considering safety, preparing budgets, purchasing materials, liaising with contractors, attracting sponsors, informing media and JCU legal of associated activity, overseeing work contracts and organizing an official handover to the client with a professionally made didactic or plaque. Our works have been celebrated at various levels internally at the University, through local media and interviews, through the Townsville City Council Limelight Award 2009 and the Qld Regional Arts and Culture Awards, 2008 and 2009.

As a learning conduit for pre-service teachers, public art projects facilitate many simultaneous skills and experiences. The list is impressive - imagination and design-based problem solving; working with new art media techniques; literacy and maths skills; research and ICT skills; community engagement and active citizenship; policy awareness, safety and QA processes; intellectual property issues and attribution; collaboration and compromise; punctuality and time management; public speaking; privacy and media release issues; respect for place; enjoyment and a special sense of achievement and belonging. Large scale artworks cannot be completed without teams being cohesive and fully committed. There are deadlines and standards while keeping sponsors, grants bodies and the clients community onside and staying friends with collaborating artists.

In some of our projects a client group has approached the University directly to initiate a work and provided funding. In some cases the works have been the result of competitive 
grants. At other times works have germinated during quite casual conversations within the university about an issue or theme that offers potential for tangible forms and we have sourced internal funding creatively. One such example was The 2008 Learning Circles in the Eddie Koiki Mabo Library Townsville - a First Year Welcoming and Retention Strategy. At the 2009 National First Year Higher Education Conference, this use of community art by a University was confirmed as an Australian first.

In almost every JCU School of Education project, community or client groups have been involved at various stages - concept design, media and technique, making, and installation. Education students are always involved from start to finish. Significantly, some teaching graduates are taking the initiative and designing their own projects with and for school communities. For teacher education this is indeed an exciting development which is a direct outcome of participation in public art projects at undergraduate level. Ultimately, our JCU public art projects are as much or more about connecting people to each other and to places and spaces, than being about art for art's sake (Berk, 2001).

The projects we have completed transcend age, gender, culture, language and religious groups, enhancing community cohesion. They are tangible examples of how public art can be a model for cultural expression, imagination and diversity, with education the continuous vital thread. The imagination and input of JCU student teachers, our community partners and sponsors is to be commended. After ten years of continuous work in this area I can confidently state that the positives far outweigh the negatives and that community-building has been the most important outcome of our collaborative endeavours. The art works are important too. They echo the people involved, their diversity, their respectful connectedness and collective sense of achievement. They have been linked together at this time, in this tropical place, through the powerful education conduit of public art.

In the second half of the written conference paper, works which have been scrolling on the slideshow are detailed. Information includes titles of the works, year of production, media and techniques used, scale, location, purpose, symbolism, timeframe, cost, environmental impact and ways of offsetting this, signage, shelf life, maintenance and community benefits. Clearly some projects have been more challenging than others but each has been a conduit for University Community engagement and, significantly, for imagination. There is insufficient time and no specific need to present these details in this conference context. The visuals 
illustrate the imaginative focus. All of these works and are also viewable at http://lindaashton.weebly.com/

To conclude this conference presentation, the current project for 2009-2010 will be illustrated briefly. Called "Nursing Rocks!" it is for the $20^{\text {th }}$ Anniversary of The School of Nursing, Midwifery and Nutrition. Twenty four mosaic panels on 6 large granite boulders, will be installed in the grounds near the main Townsville building. Head of School Assoc. Prof. David Lindsay approached me after seeing The Learning Circles in JCU's Eddie Mabo Library 2008. He and academic and professional staff wanted to celebrate their School's special milestone with a commemorative public artwork, a time capsule and some community engagement. After community and staff consultation the Rocks project was hatched. The School of Nursing will fund the project to be completed by mid 2010 when the rocks \& didactic will be officially handed over to JCU. The original dedication rock from 1989 has been moved to the new site and will be part of the 2010 public art installation. The 6 new rocks are geographically aligned ... Townsville, Cairns, Thursday Island, Mt.Isa, Fiji and External and imagery will symbolise the tropical and outback places involved. Remote communities will also be doing some of the practical application at their sites. Nursing lecturing staff who travel for teaching will have basic technique training and take some panels and equipment on visits early in 2010.

When local groups, their connectedness, and the environment are more important than the art or individual artists, the works not only look quite different, they are conduits for different thoughts and actions. When these 'public' works are gifted to community, rather than sold, then the purpose for and intent of the art enters a completely different realm. The School of Education is very proud to be part of this imaginative JCU difference in the tropical region.

Please email Questions/comments to Linda.Ashton@jcu.edu.au

\section{Knowledge in the North 2000}

Media techniques \& scale $10 \mathrm{~m} \times 1.5 \mathrm{~m}$ ceramic relief mural.

Location \& theme, Purpose \& context Imagery and symbolism of NQ . The work adorns the School of Education student notice board area near a lecture theatre on Western Campus. Timeframe - one semester, 30 students.

Environmental impact - medium with kiln firing of clay pieces. 
Cost - $\$ 600$ for materials.

Insurance - nil.

Ownership - JCU

accessibility $24 / 7$

Vandalism security theft - No damage in 9 years of installation.

Signage - professional wall mounted plaque with all student names and project management. Shelf life -the life of the building.

Community benefit - continuous visual reminder of the tropical and outback place, reef icons, cultural icons and NQ environment. These include - rainforest, reef, land forms, sporting teams, animals, Aboriginal and Torres Strait totems and large lettering embedded in the work.

\section{McCoral Reef 2001}

Media techniques \& scale $6 \mathrm{~m}$ x $4 \mathrm{~m}$ ceramic relief mural.

Location \& theme, Purpose \& context : Celebrating the vibrancy and fragility of the Great Barrier Reef. Over 1500 hand made ceramic shapes, plants and animal life. Installed as 6 play panels with pieces adhered and sand textured background.

Timeframe - one semester, 30 students.

Environmental impact - medium with kiln firing of clay pieces. Glass protective case.

Cost - $\$ 4000$ for materials and installation sponsored by local McDonalds franchisee. Insurance $\$ 20000$.

accessibility 24/7 viewable to public in outdoor sidewalk eating area of North Ward Café. Vandalism security theft - protected by glass. No damage in 8 years of installation. Signage - professional plaque with all student names and project management etc. Shelf life -25 years+ or the life of the restaurant.

Community benefit - continuous visual reminder of the tropical place, reef icons and NQ environment. Children especially enjoy looking for and naming all of the creatures lurking amid coral and seaweed.

Mosaic Garden Tables for Townsville Campus JCU (2002-2004)

Media techniques \& scale - Mosaic tile on old concrete tables.

Location \& theme Purpose \& context - Beautification, rejuvenation and hygiene.

Environmental impact - minimal due to recycled table settings and small quantities of tiles, 
glue and grout.

Ownership - JCU

Safety - some tables which had been on unstable on grass for many years were set into more stable concrete slab by Buildings and Grounds staff.

Signage - nil.

Vandalism - nil.

Shelf life - indefinite.

Community benefit - seating, social interaction, outdoor study, fresh air, easy-clean surface, regional imagery in designs.

\section{The Welcome Wall 2005}

Media techniques $\&$ scale - 288 glass Wolke blocks in a $5 \mathrm{~m}$ x $3 \mathrm{~m}$ curved free standing metal frame.

Location \& theme Purpose \& context - Grounds of Townsville Hospital outside Ronald McDonald House created for sick children and their families from remote places. A colourful entrance for the otherwise drab grounds. Mosaic look in daylight with illuminated stained glass at night. Sun/moon stars, house, flowers, animals and figures. Educational booklet for various ages for reading, writing, counting, classifying, science and comprehension.

Timeframe 1 year and made collaboratively by 25 students.

Environmental impact - high. Used some new and some recycled coloured glass, glues, concrete, electrics and metal.

Cost - Privately sponsored by George Colbran and 15 local businesses including Bunnings Warehouse. $\$ 10000$ for materials, architect approvals and installation.

Insured for $\$ 30$ 000. Successful claim when wall was tragically destroyed. The Hospital administrator at the time insisted on a footbridge being built by the University rather than the RMH Board-approved replacement public art structure which would recycle undamaged glass blocks. JCU withdrew from the second project. The footbridge has not been built and fate of the $\$ 30000$ unknown.

Ownership - Qld Health

Accessibility - was viewable 24/7.

Safety - cyclone rated and architect approved plans for free-standing structure.

Signage Vandalism, Shelf life - originally 20 years. An unlicensed drink driver rammed and destroyed the structure one year after its installation. 
Community benefit - children sat with parents, carers, volunteers and medical staff in between treatments or when recuperating. Siblings also enjoyed the work. Carols by Candlelight was held with the illuminated wall as a backdrop in December 2005. The passing public admired the brightly lit structure as they entered and left the hospital grounds ... It was a cheerful work in what can often be a very sad place to visit.

\section{Parklands Petals 2006}

Location \& theme (Floral work for Parklands Nursing Home Thuringowa Drive)

Media techniques \& scale Timber, mirror, plastic and decorative stones. The interactive wall puzzle spans a corridor near the reception. $5 \mathrm{~m} \times 2 \mathrm{~m}$. Interactive section is at wheelchair height.

Purpose \& context A mind and hand co-ordination game to stimulate creative play in a fun atmosphere. The flower petals and stem, with magnetic features, can be dismantled and reassembled in many different colour and textural combinations. They can also be stacked in a design built colourful storage cupboard with matching and sorting. Two budgies adorn the top of the cupboard as Parklands Pets - elderly residents have often had to part with their own pets on admission.

Timeframe - one semester 2006.Six students worked collaboratively

Environmental impact - low. Mostly left over items from previous projects.

Cost - funding source sponsorship insurance. Qld Health.

Ownership, accessibility. Permanent installation indoors at the nursing home. Donated by JCU.

Vandalism security theft - minimal risk. Visiting grandchildren do play with the pieces but have not caused any damage.

Safety - all mirror mosaic has smooth edges for safe touch.

Signage - plaque mounted on colourful storage cupboard.

Shelf life - durability, maintenance \& decommissioning. 15 years expected. Small replacement stones and glue left with staff at reception for minor repairs.

Community benefit - many elderly nursing home clients are very bored. They may or may not have various sensory impairments and with dementia patients, some loss of usual functioning. Puzzles and stimulating physical environments have been documented in research to counter and delay such impairment. By playing with the puzzle they interact with staff, family and each other in ways that are fun and memorable. 


\section{Coburn Tributes x3 2006}

\section{Canticle of the Sun II, Primordial Garden II and Paradise Garden II}

Media techniques scale - each approx $1.3 \mathrm{~m}$ x $2 \mathrm{~m}$ mosaic on ply

Location \& theme Federation Place, Sturt Street; Wesley Mater Hospital Hyde Park; and Tyto Wetlands Visitor Information Centre, Ingham (Coburn's birthplace and childhood home).

Purpose \& context - Celebrating the iconic tropical works of John Coburn. We communicated directly with the elderly artist about the mosaic tributes, until his sad and sudden passing in late 2006.

Timeframe - Full semester, 2006 with 5 or 6 students working on each tribute.

Cost - $\$ 500$ each for materials sponsored by Superior Concept Tiles and Combined Metal Fabrications. Each work is insured for $\$ 4000$ - \$6000.

Ownership - on permanent loan from JCU to display venue /community group - Canticle of the Sun to the Denyer family, Primordial Garden to Mater Hospital and Paradise Garden to Hinchinbrook City Council.

Accessibility - foyer, reception and corridor of large buildings open to the public daily. Vandalism security theft - minimal risk indoors

Signage - plaques installed

Shelf life - indefinite

Community benefit - Beautification, identity and history including information about and celebration of John Coburn's iconic tropical style. His Ingham relatives and Shire Mayor traveled and attended handovers for all 3 tributes. The Tyto Wetlands opening also had a traditional welcome to country for Paradise Garden II.

\section{Nativity Scene 2006}

Media \& techniques - painted timber sections, life sized diorama.

Location \& theme - Revitalised stable scene of the birth of Christ for The Good Shepherd Home.

Purpose \& context - DFor over ten years the traditional nativity installation has been erected annually on December 1 for enjoyment of elderly residents, staff, visitors and the passing public. The scene is visible from the main road and is now lit at night with a feature mirror mosaic star above the stable. It had weathered over the years and suffered major vandalism and theft of some pieces.... lost sheep. 
Timeframe - one semester. Approx 5 students with the Rotary Club of Mundingburra assisting at working bees and through sponsorship.

Environmental impact - minimal. The remaining panels from the previous version were strengthened and new panels added with brightly painted surfaces and a stained glass look.

Cost \& insurance. Materials cost $\$ 500$ met by Rotary Club. Insured for $\$ 4000$.

Ownership - The Good Shepherd Home.

Accessibility - 24/7 in December each year.

Vandalism security theft - the panels have to be chained to concreted bolts. Major vandalism one week after the first display in 2006 was repaired within 48 hours. There have been no further attacks.

Signage - Plaque in foyer of the Home.

Shelf life, maintenance \& durability - stored indoors for 11 months. In full tropical weather for one month per year. Annual structural checks, painting touch up/varnish. Expected to last 10-15 years.

Community benefit - Seasonal religious celebration.

\section{The Toddler Totem Trails 2007}

Media techniques - wooden and plastic bollards with ceramic name plaques attached.

Location \& theme - 400 0-8yrs children's names and birthdates recorded on the plaques and installed in 3 local parks - Vincent, Heatley and Gulliver.

Purpose \& context - to celebrate young children and for families to enjoy the outdoor areas, walking to and visiting the plaques.

Timeframe -18 months with 6 family fun days, entertainment and sausage sizzles in the parks. At these free events families made the clay impressions and selected decorative items to adorn the fired pieces. $50 \mathrm{JCU}$ students and Rotarians fired, decorated and attached the name plaques to the bollards which were transported to the 3 sites and installed by contractors.

Environmental impact - medium. 50\% recycled paper clay, bollards, screws, glue, bling and paint.

Cost \& Sponsors - \$30 000 grant from The Smith Family and Good Beginnings Australia. Community partners - Communities for Children and Mundingburra Rotary Club, Life Be In It Community Carpentry, Bendigo Bank.

Ownership - Townsville City Council. 
Accessibility - 24/7.

Vandalism - two major vandalism attacks in one park. 45 plaques replaced. Vandalism response plan to be activated by local Communities for Children group.

Signage - plaques attached to bollards for sponsors.

Shelf life $\boldsymbol{\&}$ durability - very weather resistant. Maintenance checks and mowing required by TCC.

Community benefit - The making of the plaques saw people from diverse backgrounds enjoying time together and valuing the park environment and anticipating the end product. One little boy about 6 years of age announced that his name was on the bollard because 'Now he was famous'.

River of Reflections 2007 Arts Built-In \$20000 public art grant awarded to JCU

Media techniques \& scale decorative security fence $11 \mathrm{~m}$ x $3 \mathrm{~m}$ powder coated steel, laser cut steel panels and mosaic

Location - New Bohlevale Community Centre.

Theme Purpose \& context. The local community chose bird life in the Bohle and Black River areas to adorn the fence and double gate panels which enclose their courtyard, BBQ and delivery vehicle section. Bohlevale resident and community artist Janine Jumeau worked with Linda and JCU students on designs and mosaic work. Wrought iron artist Michel Benchemam did the laser cut panels and welding. Zapp Powder Coating did metal protection. Timeframe - one semester 30 students

Environmental impact - heavy. Native seedlings were planted on-site as a carbon credit strategy.

Cost - funding source Qld State Government and Project Services. Insured for \$30 000

Ownership - Bohlevale Community Centre. Accessibility - viewable 24/7 to the public.

Vandalism security theft - no vandalism

Safety - no rough edges with all mosaic pieces ground for smooth finish.

Signage - plaque made for outdoor wall space in 2007 but not installed yet by client.

Shelf life - durability, maintenance \& decommissioning - maintenance schedule provided by JCU project manager. 30 year anticipated lifespan.

Community benefit - attractive and welcoming exterior adjoining the car park for community members and visitors. Celebration of local flora and fauna which the community group wanted in the artwork. 
I'd Rather Be 2008 A BIG Book for children (A3)

Media techniques - colourful drawings \& paintings of animals, each with a short narrative poem about body image, choices, imagination, well being and self esteem.

Location \& theme - donated 40 books to local Townsville groups and charities where children are cared for eg. Red Cross, Ronald McDonald House, Townsville Community Learning Centre, The Leukemia Foundation, Tsv Hospital School, Women's Crisis Centre. Timeframe - 90 students contributed small painted experimental pieces from class to very large collaged imagery (Eric Carle style). These were digitised and Photoshopped text added. This took one semester to assemble/ print.

Environmental impact - very low. Recycled paper, card and art techniques - colour printing impact offset by seedlings planted at JCU.

Funding source - sponsorship from Budget Colour Copies and NQ Book Binders. Cost per book approx $\$ 60$.

Ownership - L. Ashton IP.

Audience - children age 1-10yrs.

Vandalism security theft - wear and tear from overuse!!!!

Signage - on front and back book covers

Community Benefit - children whose lives have been dramatically impacted by poor health, social trauma and medical intervention have a special book at their hospital/local charitable organization to enjoy. It gives them hope that things are possible and that sometimes even if we aren't happy with the person we are, slight changes in thinking can help turn this feeling around.

\section{The Learning Circles 2008}

Media techniques scale $-22 \mathrm{~m} \times 4 \mathrm{~m}$ relief ceramic mural using recycled paper clay, pebbles, laser cut mirror, and glass nuggets.

Location theme purpose \& context Trialled as a welcoming strategy for new first year students to form social and study networks. $2500+$ new students chatted casually while making a clay a mandala or two during O-week and early classes. The final work with over 4000 pieces was installed in the Eddie Koiki Mabo Library in Townsville on the ground floor near the Learning Centre where students go for academic support.

Timeframe -2008 Feb to Nov 2008

Environmental impact - minimal with very low tech media. 4 kiln firings offset by 
seedlings strategy. Cost - \$2500 funding from School of Education and Teaching and Learning Development. Sponsorship -Twin Cities Glass and Aluminium.

Insurance - valued at $\$ 25000$.

Ownership JCU. Accessibility - open to students, staff and visiting public during library hours.

Vandalism security theft - Minimal risk indoors with library and academic support staff in close proximity.

Signage - official plaque installed at handover $\left(40^{\text {th }}\right.$ anniversary of the opening of the library).

Shelf life - durability, maintenance \& decommissioning, Indefinite timeframe - very durable.

Community benefit - many new JCU students, staff and local people contributed to the work and now have a tangible personal connection with the library space. At the 2009 FYHE National Conference in July, the Learning Circles Project was confirmed and celebrated as a first as an Australian University retention strategy. A 2009-10 B.Ed Hons research study will track ways in which the strategy may have enhanced early networks, study connections and support for first year students. The University of Newcastle (Ourimbah Campus) will implement a similar public art project in $\mathrm{O}$ - week 2010 with their new Indigenous students, based on the JCU Learning Circles model.

Nursing Rocks 2009-2010 The $20^{\text {th }}$ anniversary of the School of Nursing, Midwifery and Nutrition commences on October $9^{\text {th }} 2009$. To mark the milestone, tropical imagery for each of the School's six locations will be mosaiced onto granite boulders (locally sourced from JCU campus). The six sites are Townsville, Cairns, Thursday Island, Fiji, Mt. Isa and External programs. Imagery includes tropical forms eg. a mud crab, flat back turtle, frigate bird and red parrot, bilby, dugong, carpet snake, box jellyfish, tree frog, rainforest plants and wildflowers. Totems and icons from the tropics also include the Torres Strait Dhari, Aboriginal flag colours, healing hands, technology and the www, kava ceremony, rodeo scene and local landforms.

Media techniques - photoshop designs, digital photography, mosaic panels on granite rock. Staff from each location will take a design to their site for community involvement in the mosaic process.

Location \& theme - The completed rock installation will be at the Nursing Sciences 
building in Townsville with a digital record on the www. Tropical imagery and significant symbolism will mark each rock. The group of 6 rocks have been arranged on the ground in relevant geographic positions.

Timeframe - Education students and School of Nursing staff will work on the mosaic panels from September 2009 till end May 2010. A time capsule of the School's history for its first 20years will be buried under one of the boulders.

Environmental impact - low. Natural rock, small quantities of ceramic tiles, glue and grout. Funding source - School of Nursing, Midwifery and Nutrition with sponsorship from Concept Tiles.

Ownership - JCU - the installation. L. Ashton IP.

Audience - JCU staff, students and visitors.

Vandalism security theft - minimal.

Signage - laser cut lettering on each rock and a wall mounted plaque on the building.

Community Benefit - celebration of a milestone and contribution of one of the University's oldest Schools. Documentation stored in secure time capsule for future generations.

\section{BIBLIOGRAPHY}

Anderson, P. (2001) Against the "Plonk" approach to public art. Art \& Australia 18 (2), 4041.

Bach, P. (2001). New Land Marks: Defining the Public Context. US: Fairmont Park Art Association

Baxter, M. (1998). The community as public art practitioner. Good or bad idea? Artlink, 18 (2), 73-75.

Berk, A. (2001). Are people more important than art? Artweek, 32, 15-16.

Brecknock. R. (1992) Public art public places public

money. http:/www.gu.edu.au/centre/cmp/4-07-brecknock.html.

Cohn, T. (2001). Place, history and public art. Artweek, 32, 12-13.

Dissanayake, E. (2001). Why public art is necessary. New Land Marks. Ed. Penny BalkinBach, Fairmont Park Art Association, U S. 
Erikson, D. (1998). Entrepreneurs and public Art. Artlink, 18 (2), 70-72.

Holt, R. (2000). The appeal of the temporal. Artlink, 20 (4), 59-61.

Kins, A. (1998) . Percent for art in the West. Artlink, 18 (2), 76-77.

Lally, J. (1998). A moment of reflection: Public art, the art for public places.

MacGowan T. (2000). Heroism in the public domain. Artlink, 20 (4), 37-42.

Malone, G. (1997). Going public ... Doin’ it in the street. Artlink, 17 (2), 54-55.

Miles, C. (2001). Conversations with Barbara McCarren and Jud Fine. Artweek, 32, 14-15.

Miles, M. (1997). Art, Space and the City: Public Art and Urban Futures. London:

Routledge.

Miller, A. (2000). Space adventures. Artlink, 20 (4), 34-36.

Miller, A. (2001). The growing impact of environmental art. Artweek, 32, 17.

Miller, N. (2000). It is the edges that make it interesting. Artlink, 20 (4), 30-33.

Morrell, T. (2000). Stafford and staff: Queensland's Public art agency. Artlink, 20 (4), 65-66.

Ohlin, J. (1998). Local government and public art. Artlink, 18 (2), 66-67.

Queensland Government (2007) Art + Place accesses July $12^{\text {th }} 2009$

http://www.arts.qld.gov.au/funding/pub-art-funds.html

Taylor, R. (2001). Shelf-life, use-by date and other related issues. Public Art: When the honeymoon is over. Artlink, 18(2), 16-18.

\section{Presenter:}

Dr Linda Ashton 0419713242 linda.ashton@jcu.edu.au

http://lindaashton.weebly.com/ 


\section{Bio}

Linda Ashton is senior lecturer for arts education at James Cook University. She works with pre-service teachers in Townsville, Cairns and remote sites, and advocates for learning, literacy and active citizenship which are enriched particularly by collaborative, visual art experiences. From 2000 to 2003, Dr. Ashton was editor of the Australian Institute for Art Education's scholarly journal Australian Art Education. Her research informed teaching and community engagement have been awarded local, state and national commendation including a 2007 National Carrick citation for outstanding contribution to student learning. In $1999 \mathrm{Dr}$ Ashton won the JCU VC's inaugural Teaching Excellence Award. In 2009 Linda received Townsville City Council's Limelight Award for sustained outstanding contribution to the cultural life of Townsville and is a finalist in the 2009 Queensland Regional Arts and Culture Awards.

When the moment has gone, as it just has, we have dreams, memories, stories and art.

\section{Useful Public Art URLS}

http://www.ozco.gov.au/

http://www.ozco.gov.au/

http://www.grantslink.gov.au/

http://www.artsinfo.net.au/

http://www.arts.qld.gov.au/funding/pub-art-funds.html

http://www.qld.gov.au/grants/grantdetails.action?grantId=8ae5936c15ecb4cf0115ecb4ddf300 $\underline{01}$

http://www.arts.qld.gov.au/docs/keniger-report.pdf

http://www.townsville.qld.gov.au/default.asp

http://www.townsville.qld.gov.au/community_info/cic/cic_arts_ebulletins.htm

http://www.qac.org.au/ 
http://www.alicesprings.nt.gov.au/astc_site/community/arts_and_culture/public_art/public_ar t_policy

http://www.townsville.qld.gov.au/recreation/gallery/perctucker/strand_ephemera/index

http://www.bendigo.vic.gov.au/

http://wran.org.au/

http://www.regionalarts.com.au/links.html

http://www.publicartaroundtheworld.com/

http://www.lgsa.org.au/www/html/416-public-art-policy-and-planning-for-localgovernment.asp

http://www.lgsa.org.au/resources/documents/Eurobodalla_Public_Art_Policy.pdf http://www.communityarts.net/readingroom/archivefiles/2008/12/going_green_wit.php http://www.scottisharts.org.uk/1/information/publications/1005741.aspx

http://www.bodyworlds.com/en/gunther_von_hagens/life_in_science.html

http://www.bodyworlds.com/en/exhibitions/current_exhibitions.html

http://mainearts.maine.gov/public/index.shtml

Www.willisnewson.co.uk/ services/index.html

http://www.rockingham.wa.gov.au/Community_Services/culture-arts-events.php

http://www.pps.org/Public_Art/art_am.html

http://www.monitor.net/monitor/free/whosehistory.html

http://www.artslynx.org/heal/public.htm

http://www.art-public.com/ 
http://www.guardian.co.uk/artanddesign/artblog/2008/may/11/artinpublicspacesshouldbe http://www.artandarchitecturejournal.com/pages_gb/tup_current.html\#Art\%20in\%20Health http://www.publicartonline.org.uk/resources/research/healthy_hospitals.php http://www.thinksculpture.com/html/portfolioA.html http://images.google.com.au/imgres?imgurl=http://www.craftaustralia.org.au/library/docfiles/ reviews/notes_for_a history/images/Australia\%2520Council\%2520Public\%2520Art\%2520P rogram,\%2520Bert\%2520Flugelman,\%2520Twin\%2520Spheres,\%25201977,\%2520Stainles s\%2520steel.\%2520Rundle\%2520Mall,\%2520Adelaide.\%2520Photo\%2520R\%2520Fazaker ley..jpg\&imgrefurl=http://www.craftaustralia.org.au/library/review.php\%3Fid\%3Dnotes_for a_history\&usg=_pa2gKRQtF2LJezQ-

http://images.google.com.au/imgres?imgurl=http://www.rockingham.wa.gov.au/img/publicart-wave-lg.jpg\&imgrefurl=http://www.rockingham.wa.gov.au/Community_Services/culture$\underline{\text { arts- }}$

events.php\%3Fyear\%3D2007\&usg= ZwhnpTdqlBgl7Er0dNipy 9E0V4=\&h=1047\&w=70

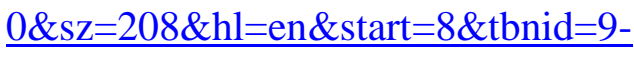

DEsx8vfwFSfM:\&tbnh=150\&tbnw=100\&prev=/images\%3Fq\%3Dpublic\%2Bart\%2Baustrali a $26 \mathrm{gbv} \% 3 \mathrm{D} 2 \% 26 \mathrm{hl} \% 3 \mathrm{Den} \% 26 \mathrm{sa} \% 3 \mathrm{DG}$

http://kimgrantmosaics.wordpress.com/2007/01/09/green-and-golden-bell-frog-sydneyairport/

http://images.google.com.au/imgres?imgurl=http://www.publicartaroundtheworld.com/image s/L25ADIG-

Australia.gif\&imgrefurl=http://www.publicartaroundtheworld.com/\&usg= 16nD6hwHaqtn 9hwF-

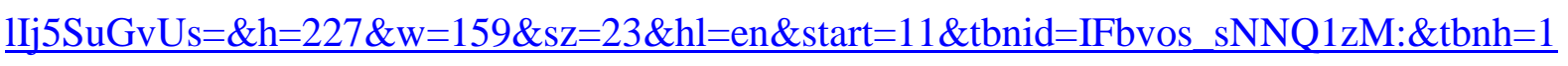
$\underline{08 \& \text { tbnw }=76 \& \text { prev }=/ \text { images } \% 3 \mathrm{Fq} \% 3 \mathrm{D} \text { public } \% 2 \mathrm{Bart} \% 2 \mathrm{Baustralia} \% 26 \mathrm{gbv} \% 3 \mathrm{D} 2 \% 26 \mathrm{hl} \% 3 \mathrm{D}}$ en $\% 26 \mathrm{sa} \% 3 \mathrm{DG}$

http://images.google.com.au/imgres?imgurl=http://www.mytko.org/random/beever/JBpoolW RONG.jpeg\&imgrefurl=http://mytko.org/random/2008/03/julian-beevers-amazing-chalk- 
drawings.html\&usg= dA1vPz1I1tQjiCQsLHEMvG-

$\underline{\mathrm{WMDM}}=\& \mathrm{~h}=300 \& \mathrm{w}=400 \& \mathrm{sz}=25 \& \mathrm{hl}=\mathrm{en} \& \mathrm{start}=1 \& \mathrm{tbnid}=\mathrm{GSQwSR} 11 \mathrm{uNmJOM}: \& \mathrm{tbnh}=93$

\&tbnw=124\&prev=/images $\% 3 \mathrm{Fq} \% 3 \mathrm{Djulian} \% 2 \mathrm{Bbeever} \% 2 \mathrm{Bhomepage} \% 26 \mathrm{hl} \% 3 \mathrm{Den} \% 26 \mathrm{sa}$ $\underline{\% \mathrm{DG}}$

http://www.askart.com/askart/artist.aspx ?artist=70738 